\title{
Analysis of Physicochemical and Sensory Quality of Chia Seeds Sport Energy Gel (Salvia hispanica, L.) during Storage
}

\author{
Yanesti Nuravianda Lestari ${ }^{1}$, Eko Farida ${ }^{2}$, Nur Fauzi ${ }^{3}$, Fadjrul Falah Fikri ${ }^{4}$ \\ \{yanestinur@mail.unnes.ac.id ${ }^{1}$,f_rida_mw@yahoo.com ${ }^{2}$, nurfauzi@students.unnes.ac.id ${ }^{3}$ \} \\ Universitas Negeri Semarang, Semarang, Indonesia ${ }^{1,2,3,4}$
}

\begin{abstract}
Sports drinks could be applied as sports food for athletes during the training and recovery stage. This study aimed to formulate a sports energy gel from Chia seeds (Salvia hispanica, L.). This study conducted on a total of 18 treatments were consist of 2 factors (hydrocolloid type and storage temperature). The observed characteristics were $\mathrm{pH}$, total soluble solids (TSS), and physical and sensory changes due to storage. The results show that there is a significant difference in the $\mathrm{pH}$ and the total soluble solids. During storage, the color is getting darker, cloudy, froth, and rolled, and its acids and alcohol odor increased in all the treatment stored at room temperature compared with refrigerator temperature storage. It can conclude that different types of hydrocolloid and storage temperatures can significantly decrease the physical quality and sensory characteristics.
\end{abstract}

Keywords: sports energy gel, hydrocolloids, sensory characteristics.

\section{Introduction}

Sports drinks created to revitalize the electrolyte and keep the body hydrated. Sports drinks could be applied as sports food for athletes during the training and recovery stage. The most important ingredient of sports drinks are carbohydrates, mainly glucose and electrolyte (sodium, potassium, and magnesium). Athletes need sports drinks during hard physical activity to avoid hyponatremia, which causes fatal because of a lack of sodium level in the blood. The first sports drink produced for the football team in Florida is Gatorade, which has liquid form. Sports drinks are now growing in another form, such as sports gel.[1] Sports gel has gooey consistency and concentrated carbohydrate, usually available in a single pack.

The component of a food ingredient that can use as a source of energy and nutrient in formulating sports drinks is Chia seeds (Salvia hispanica L.). Chia seeds have a small oval shape, usually black, gray, or brown, with few white spots. In the water, Chia seeds can expand and produce clear white mucus. Chia seeds are also often used as components in the manufacture of certain food products and function as thickener, emulsifiers, or stabilizers.[2],[3] Chia seeds are high in fiber, protein, omega-3, gluten-free, rich in vitamins, minerals, and antioxidants, namely polyphenols, tocopherols, and isoflavones.[4],[5] 
Athletes are not able to consume much fluid in one drink, especially during vigorous exercise. Athletes need adequate energy, nutrients, and electrolytes to support their performance during training. One of the sports drink that can be applied on athletes is sports energy gel, which produces with hydrocolloid addition. The hydrocolloid is a component to bind the water and form gooey consistency. The hydrocolloid also uses as a thickener, gelling agent, emulsifier, stabilizer, and coating, for example, carboxymethyl cellulose (CMC), gelatin, chitosan, gum, pectin, and starch.[6] This research was conduct to develop and produce sports energy gel based on Chia seeds and hydrocolloid addition, which has the best physicochemical and sensory quality.

\section{Material and methods}

This Complete Random Design study is consists of two factors, hydrocolloid type and storage temperature. The hydrocolloid $(\mathrm{H})$ type factor consists of 3 levels, while the storage temperature factor $(\mathrm{T})$ consists of 2 levels. Each treatment level replicated three times, so that there are total 18 treatments.

\subsection{Preparation of sport energy gel}

The main ingredients used in the preparation of sports energy gel are organic Chia seeds (Salvia hispanica, L) purchased at local supermarkets. The hydrocolloids used in this beverage formulation are xanthan gum, pectin, and Carboxymethyl Cellulose (CMC). Other ingredients used as beverage composition are dragon fruit juice and cucumber juice.[1],[2] The composition of Chia seeds-based sports energy gel presented in Table $\mathbf{1 .}$

Table 1. The Composition of Chia Seeds-based Sport Energy Gel.

\begin{tabular}{ll}
\hline Ingredients & Amount \\
\hline Chia seeds $(\mathrm{g})$ & 4 \\
Maltodextrin $(\mathrm{g})$ & 15 \\
Dragon fruit juice $(\mathrm{mL})$ & 5 \\
Cucumber juice $(\mathrm{mL})$ & 5 \\
Hydrocolloids $(\%)$ & $0.1 \%$ \\
Water $(\mathrm{mL})$ & 200 \\
\hline
\end{tabular}

The production of a sports energy gel is done by mixing Chia seeds, maltodextrin, dragonfruit juice, cucumber juice, and added warm water as much as $200 \mathrm{~mL}$. The mixture homogenized and then added $0.1 \%$ hydrocolloids $\left(\mathrm{H}_{1}\right.$ : Xanthan Gum; $\mathrm{H}_{2}$ : Pectin; $\mathrm{H}_{3}$ : CMC). The mixture then homogenized.

\subsection{Storage of sport energy gel}

Sport Energy gels that have formulated and added hydrocolloids then stored for seven days at different storage temperatures, which are room temperature $15-30^{\circ} \mathrm{C}\left(\mathrm{T}_{1}\right)$ and refrigerator temperature $8^{\circ} \mathrm{C}\left(\mathrm{T}_{2}\right)$. The observation of the characteristic changes occurred four times, there is the day before storage (day 0 ) and during storage at day $3^{\text {th }}, 5^{\text {th }}$, and $7^{\text {th }}$. 


\subsection{Physicochemical analysis of sport energy gel}

Acidity (pH). The pH of a sports energy gel is measured using a pH-meter. Before measuring the sample, the $\mathrm{pH}$-meter calibrated first using a buffer solution. The $\mathrm{pH}$-meter dipped in $100 \mathrm{~mL}$ of a homogenized sample.[3]

Total Soluble Solid (TSS). The Total Soluble Solid (TSS) of sports energy gel is measured using a hand refractometer. Before measuring the sample, the refractometer calibrated first using aqua dest until the reading results indicate a zero value. 1-2 drops shed the sample on the glass prism. Cover the glass prism slowly and make sure the sample fills the entire glass surface prism. The Total Soluble Solid (TSS) level is read through the binoculars and will designate as Brix [4].

\subsection{Sensory analysis of sport energy gel}

Organoleptic Analysis. Organoleptic analysis of sports energy gel conducted by observing texture (consistency), color, and aroma. Observation of organoleptic characteristics is performed one time for each day during seven days of storage of sports energy gel both sampleat room and the refrigerator temperature [5].

Homogeneity Analysis. Sports energy gel was observed its homogeneity by applying 1-2 drops of samples on glass objects then observed dispersion or spread. The homogeneous sample if the entire sample composition can disperse evenly [5].

\subsection{Data analysis}

Data were analyzed using SPSS 16.0 for Windows. Physicochemical analysis data of sports energy gel during storage period analyzed with One-Way and Two-Way ANOVA with a confidence level of 95\%, which then continued with Duncan Multiple Range Test (DMRT) test. As for the differences in physicochemical characteristics of sports energy gel stored in room temperature and refrigerator temperature, an analysis conducted using the independent t-test with a confidence level of $95 \%$. Data on sports energy gel sensory analysis during the storage period was analyzed descriptively through study and theoretical approach.

\section{Results and discussion}

\subsection{Physicochemical analysis of sport energy gel}

Acidity (pH). The measurement of the $\mathrm{pH}$ value of the sports energy gel sample over a 7 day storage period shows a sharp decline in the first and second days of storage in all samples (both stored at room and refrigerator temperature). The sports energy gel with the addition of xanthan gum stored at room temperature $\left(\mathrm{H}_{1} \mathrm{~T}_{1}\right)$ indicates a slight increase in $\mathrm{pH}$ value on the $4^{\text {th }}$ day until the $6^{\text {th }}$ day and decreases on the $7^{\text {th }}$ day of storage. The sample 
stored in the refrigerator temperature $\left(\mathrm{H}_{1} \mathrm{~T}_{2}\right)$ shows that its $\mathrm{pH}$ value continues to decline until the $7^{\text {th }}$ day of storage. The $\mathrm{pH}$ value of a sports energy gel with the addition of pectin stored at room temperature $\left(\mathrm{H}_{2} \mathrm{~T}_{1}\right)$ still shows a decline in $\mathrm{pH}$ until day six, and a slight increase on the $7^{\text {th }}$ day of observation.
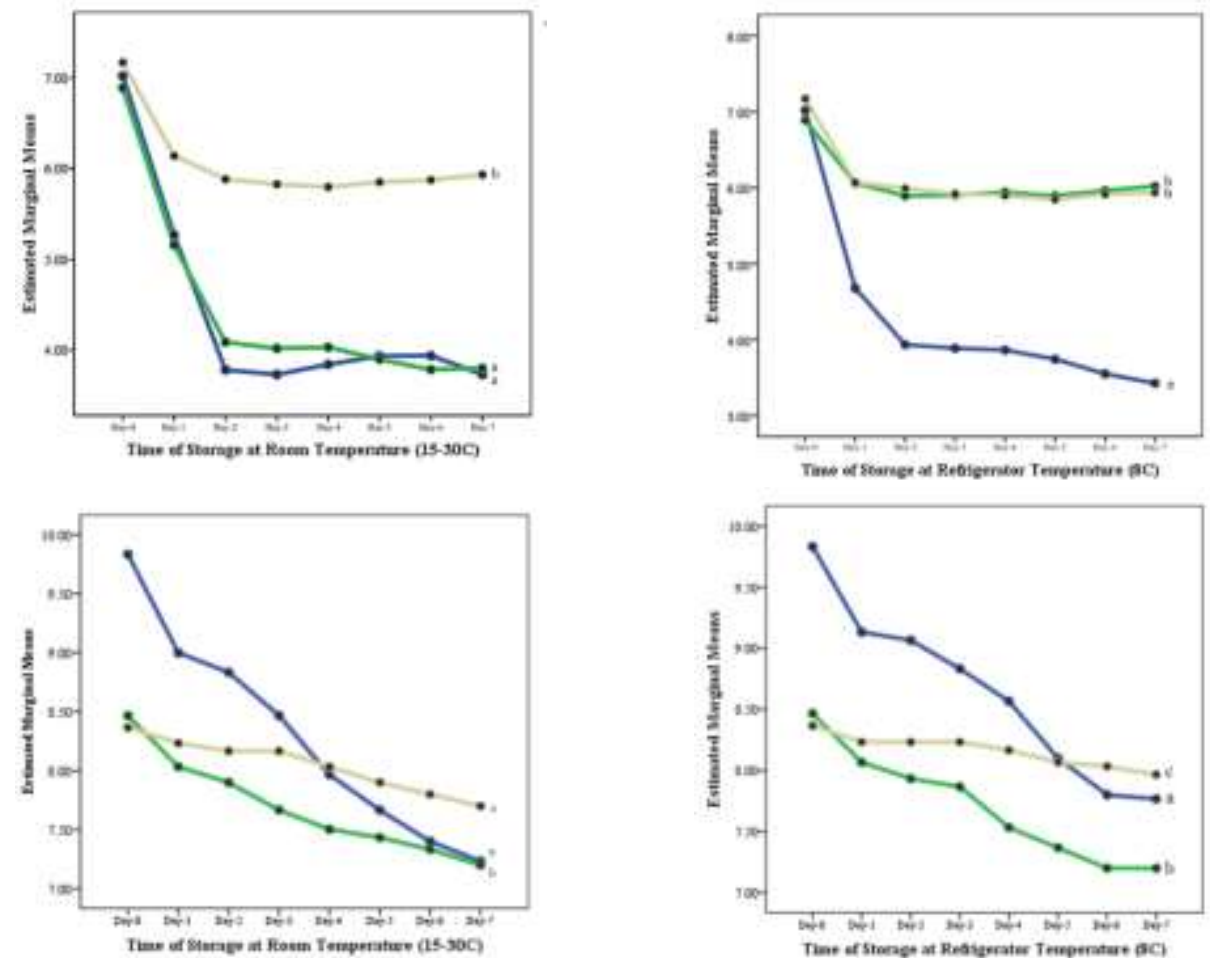

Fig. 1. a. The $\mathrm{pH}$ of Sports Energy Gel during Storage at Room Temperature. b. The $\mathrm{pH}$ of Sports Energy Gel during Storage at Refrigerator Temperature. c. Total Soluble Solid of Sport Energy Gel during Storage at Room Temperature. d. Total Soluble Solid of Sport Energy Gel during Storage at Refrigerator Temperature.

The difference means test between-subject effect using Two Way ANOVA. Comparison among treatments for a combination of time storage and type of hydrocolloids is significant at level $0.05(\mathrm{p}=0.0001)$. Comparison among treatment for time storage only is significant at level $0.05(\mathrm{p}=0.0001)$. A comparison among treatment for a type of hydrocolloids only is significant at level $0.05(\mathrm{p}=0.0001)$.

The sports energy gel with the addition of pectin stored at the refrigerator temperature $\left(\mathrm{H}_{2} \mathrm{~T}_{2}\right)$ showed a slight increase in the $3^{\text {rd }}$ day and decreased on the $5^{\text {th }}$ day, although then the $\mathrm{pH}$ value slightly increased until the $7^{\text {th }}$ day of observation. The sports energy gel with the addition of CMC stored at room temperature $\left(\mathrm{H}_{3} \mathrm{~T}_{1}\right)$ shows a decline until the $4^{\text {th }}$ day, then a little up until the $7^{\text {th }}$ day of observation. The sports energy gel with the addition of CMC stored at the refrigerator temperature $\left(\mathrm{H}_{3} \mathrm{~T}_{2}\right)$ also shows a decline until day five then the $\mathrm{pH}$ value increase until the $7^{\text {th }}$ day of observation (Fig. 1a $\& \mathbf{1 b}$ ).

Different test results using the independent t-test show no significant difference in the $\mathrm{pH}$ value between the sports energy gel stored at room temperature or refrigerator temperature $(\mathrm{p}=0.603)$. However, different test results for each day of observation show that there is a 
significant difference between the $\mathrm{pH}$ value of sports energy gel stored at room temperature and the refrigerator temperature, showed by a $\mathrm{p}$-value $<0.05(\mathrm{p}=0.0001)$ (Table 2).

Table 2. Physical Characteristics of Sport Energy Gel during Storage at Different Temperature.

\begin{tabular}{|c|c|c|c|c|c|c|c|}
\hline \multirow{3}{*}{ Day } & \multirow{3}{*}{$\begin{array}{c}\text { Type of } \\
\text { Hydrocolloids }\end{array}$} & \multicolumn{3}{|c|}{$\mathbf{p H}$} & \multicolumn{3}{|c|}{$\begin{array}{c}\text { Total Soluble Solid } \\
\end{array}$} \\
\hline & & \multicolumn{2}{|c|}{ Storage Temperature ${ }^{\mathrm{s}}(\S)$} & \multirow{2}{*}{ P-Value } & \multicolumn{2}{|c|}{ Storage Temperature ${ }^{\mathrm{s}}(\S)$} & \multirow{2}{*}{ P-Value } \\
\hline & & $15-30^{\circ} \mathrm{C}\left(\mathrm{T}_{1}\right)$ & $8^{\circ} \mathrm{C}\left(\mathrm{T}_{2}\right)$ & & $15-30^{\circ} \mathrm{C}\left(\mathrm{T}_{1}\right)$ & $8^{\circ} \mathrm{C}\left(\mathrm{T}_{2}\right)$ & \\
\hline \multirow[t]{3}{*}{0} & $\mathrm{H}_{1}$ & \multirow{3}{*}{\multicolumn{2}{|c|}{$\begin{array}{l}7.02 \pm 0.026^{\mathrm{a}} \\
6.89 \pm 0.010^{\mathrm{b}} \\
7.17 \pm 0.020^{\mathrm{c}}\end{array}$}} & $0.0001^{*}(\#)$ & \multirow{3}{*}{\multicolumn{2}{|c|}{$\begin{array}{l}9.83 \pm 0.153^{\mathrm{a}} \\
8.47 \pm 0.058^{\mathrm{a}} \\
8.37 \pm 0.115^{\mathrm{b}} \\
\end{array}$}} & $0.0001 *(\#)$ \\
\hline & $\mathrm{H}_{2}$ & & & & & & \\
\hline & $\mathrm{H}_{3}$ & & & & & & \\
\hline \multirow[t]{3}{*}{1} & $\mathrm{H}_{1}$ & $5.27 \pm 0.715^{\mathrm{a}}$ & $6.14 \pm 0.010^{\mathrm{a}}$ & $0.151^{\mathrm{ns}}(\#)$ & $9.00 \pm 0.100^{\mathrm{a}}$ & $9.13 \pm 0.058^{\mathrm{a}}$ & $0.001 *(\#)$ \\
\hline & $\mathrm{H}_{2}$ & $6.06 \pm 0.020^{\mathrm{a}}$ & $6.14 \pm 0.010^{\mathrm{a}}$ & $0.0001^{*}(\wedge)$ & $9.13 \pm 0.058^{\mathrm{a}}$ & $8.23 \pm 0.252^{b}$ & $0.0001 *(\wedge)$ \\
\hline & $\mathrm{H}_{3}$ & $5.27 \pm 0.715^{\mathrm{a}}$ & $6.07 \pm 0.020^{\mathrm{b}}$ & $0.0001 *(\vee)$ & $9.00 \pm 0.100^{\mathrm{b}}$ & $8.23 \pm 0.208^{b}$ & $0.473^{\text {ns }}(\vee)$ \\
\hline \multirow[t]{3}{*}{2} & $\mathrm{H}_{1}$ & $3.78 \pm 0.075^{\mathrm{a}}$ & $5.88 \pm 0.031^{\mathrm{a}}$ & $0.0001^{*}(\#)$ & $8.90 \pm 0.115^{\mathrm{a}}$ & $9.07 \pm 0.115^{\mathrm{a}}$ & $0.0001 *(\#)$ \\
\hline & $\mathrm{H}_{2}$ & $3.93 \pm 0.100^{\mathrm{b}}$ & $5.88 \pm 0.031^{b}$ & $0.0001^{*}(\wedge)$ & $7.93 \pm 0.115^{\mathrm{b}}$ & $8.17 \pm 0.058^{b}$ & $0.0001 *(\wedge)$ \\
\hline & $\mathrm{H}_{3}$ & $4.09 \pm 0.035^{\mathrm{c}}$ & $5.99 \pm 0.010^{\mathrm{b}}$ & $0.0001 *(\vee)$ & $7.90 \pm 0.100^{\mathrm{c}}$ & $8.23 \pm 0.058^{c}$ & $0.231^{\mathrm{ns}}(\mathrm{V})$ \\
\hline \multirow[t]{3}{*}{3} & $\mathrm{H}_{1}$ & $3.73 \pm 0.035^{\mathrm{a}}$ & $5.83 \pm 0.023^{\mathrm{a}}$ & $0.0001^{*}(\#)$ & $8.47 \pm 0.058^{\mathrm{a}}$ & $8.83 \pm 0.058^{\mathrm{a}}$ & $0.001 *(\#)$ \\
\hline & $\mathrm{H}_{2}$ & $3.89 \pm 0.051^{\mathrm{b}}$ & $5.83 \pm 0.023^{b}$ & $0.0001^{*}(\wedge)$ & $7.87 \pm 0.153^{b}$ & $8.17 \pm 0.058^{b}$ & $0.0001 *(\wedge)$ \\
\hline & $\mathrm{H}_{3}$ & $4.02 \pm 0.021^{\mathrm{c}}$ & $5.92 \pm 0.017^{b}$ & $0.0001 *(\vee)$ & $7.67 \pm 0.208^{c}$ & $8.23 \pm 0.115^{\mathrm{c}}$ & $0.026 *(\vee)$ \\
\hline \multirow[t]{3}{*}{4} & $\mathrm{H}_{1}$ & $3.84 \pm 0.105^{\mathrm{a}}$ & $5.80 \pm 0.045^{\mathrm{a}}$ & $0.0001^{*}(\#)$ & $7.97 \pm 0.058^{\mathrm{a}}$ & $8.57 \pm 0.058^{\mathrm{a}}$ & $0.0001 *(\#)$ \\
\hline & $\mathrm{H}_{2}$ & $3.86 \pm 0.078^{\mathrm{b}}$ & $5.80 \pm 0.045^{\mathrm{b}}$ & $0.0001^{*}(\wedge)$ & $7.53 \pm 0.153^{\mathrm{b}}$ & $8.04 \pm 0.069^{b}$ & $0.0001 *(\wedge)$ \\
\hline & $\mathrm{H}_{3}$ & $4.03 \pm 0.070^{c}$ & $5.90 \pm 0.006^{\mathrm{b}}$ & $0.0001 *(\vee)$ & $7.50 \pm 0.105^{b}$ & $8.16 \pm 0.053^{c}$ & $0.0001 *(\vee)$ \\
\hline \multirow[t]{3}{*}{5} & $\mathrm{H}_{1}$ & $3.93 \pm 0.292^{\mathrm{a}}$ & $5.85 \pm 0.010^{\mathrm{a}}$ & $0.0001^{*}(\#)$ & $7.67 \pm 0.231^{\mathrm{a}}$ & $8.10 \pm 0.100^{\mathrm{a}}$ & $0.024^{*}(\#)$ \\
\hline & $\mathrm{H}_{2}$ & $3.74 \pm 0.559^{\mathrm{b}}$ & $5.85 \pm 0.010^{\mathrm{ab}}$ & $0.0001^{*}(\wedge)$ & $7.36 \pm 0.118^{\mathrm{ab}}$ & $7.90 \pm 0.100^{\mathrm{b}}$ & $0.0001 *(\wedge)$ \\
\hline & $\mathrm{H}_{3}$ & $3.90 \pm 0.190^{\mathrm{c}}$ & $5.85 \pm 0.025^{\mathrm{b}}$ & $0.0001 *(\vee)$ & $7.45 \pm 0.047^{\mathrm{b}}$ & $8.06 \pm 0.078^{b}$ & $0.0001 *(\vee)$ \\
\hline \multirow[t]{3}{*}{6} & $\mathrm{H}_{1}$ & $3.94 \pm 0.366^{\mathrm{a}}$ & $5.87 \pm 0.040^{\mathrm{a}}$ & $0.0001^{*}(\#)$ & $7.40 \pm 0.100^{\mathrm{a}}$ & $7.80 \pm 0.300^{\mathrm{a}}$ & $0.003^{*}(\#)$ \\
\hline & $\mathrm{H}_{2}$ & $3.55 \pm 0.691^{\mathrm{a}}$ & $5.87 \pm 0.040^{b}$ & $0.0001^{*}(\wedge)$ & $7.20 \pm 0.173^{\mathrm{a}}$ & $7.80 \pm 0.100^{\mathrm{b}}$ & $0.006^{*}(\wedge)$ \\
\hline & $\mathrm{H}_{3}$ & $3.78 \pm 0.341^{\mathrm{b}}$ & $5.91 \pm 0.114^{\mathrm{b}}$ & $0.0001 *(\vee)$ & $7.33 \pm 0.115^{\mathrm{b}}$ & $8.02 \pm 0.029^{b}$ & $0.0001 *(\vee)$ \\
\hline \multirow[t]{3}{*}{7} & $\mathrm{H}_{1}$ & $3.73 \pm 0.320^{\mathrm{a}}$ & $5.93 \pm 0.068^{\mathrm{a}}$ & $0.0001^{*}(\#)$ & $7.23 \pm 0.153^{\mathrm{a}}$ & $7.77 \pm 0.306^{\mathrm{a}}$ & $0.010^{*}(\#)$ \\
\hline & $\mathrm{H}_{2}$ & $3.43+0.587^{\mathrm{a}}$ & $5.93+0.068^{b}$ & $0.0001^{*}(\wedge)$ & $7.20 \pm 0.265^{\mathrm{a}}$ & $7.70 \pm 0.173^{b}$ & $0.018(\wedge)$ \\
\hline & $\mathrm{H}_{3}$ & $3.80+0.495^{b}$ & $5.94 \pm 0.006^{b}$ & $0.0001 *(\vee)$ & $7.20 \pm 0.100^{\mathrm{b}}$ & $7.97 \pm 0.058^{b}$ & $0.0001 *(\mathrm{~V})$ \\
\hline
\end{tabular}

*Significant difference mean at the level of 0.05 (ns = not significant)

The difference means test using One Way Anova

(\#) comparison among treatment in room temperature

$(\wedge)$ comparison among treatment in refrigerator temperature

The difference means test using Independent T-Test

$(\S)$ comparison between the mean of treatment in different storage temperature $(p=0.603 ; p=0.583)$

$(\vee)$ comparison between the mean of treatment within each time of storage

Letter notation applies to have the mean of each treatment group

Notation differences show significant mean differences

The study results also show that the addition of different types of hydrocolloids in the sports energy gel formulation can make significantly different $\mathrm{pH}$ changes throughout 7 days of storage in both room and refrigerator temperature $(p=0.0001)$. The advanced test using DMRT showed that the sports energy gel added by CMC and stored at room temperature had a significantly higher $\mathrm{pH}$ value than those added xanthan gums and pectin. It is indicated with the difference in the letter notation. (Fig. 1a). As for the results of further testing on the sports energy gel stored at the refrigerator temperature indicates that the sports energy gel added xanthan gum has a higher $\mathrm{pH}$ value significantly when compared with the added pectin or CMC (Fig. 1b).

The analysis results then strengthen by an analysis of variance in each temperature treatment group in every day of observation. There is a significant difference in $\mathrm{pH}$ value on 
every day of observation in both the temperature treatment groups $\left(\mathrm{T}_{1}\right.$ and $\left.\mathrm{T}_{2}\right)$; both the sports energy gel add xanthan gum, pectin, nor CMC $\left(\mathrm{H}_{1}, \mathrm{H}_{2}\right.$, and $\left.\mathrm{H}_{3}\right)$. It is showed with a value of $\mathrm{p}<0.05(\mathrm{p}=0.0001)$, except on a sport energy gel that is stored at room temperature on the $1^{\text {st }}$ day of storage showing the value $\mathrm{p}>0.05(\mathrm{p}=0.151)$ (Table 2).

The results of this study support similar research conducted in 2015 on the tomato-carrot juice blend. The study results stated that there was no significant difference between the storage at room temperature and room temperature in the sample. The sample stored in the refrigerator temperature shows a more stable $\mathrm{pH}$ than the sample stored at room temperature. However, during the storage period, fluctuating $\mathrm{pH}$ changes occur, but it appears to be a sharp decline in the second week of storage, both stored at room temperature or refrigerator temperature. This research also shows that the $\mathrm{pH}$ value of samples stored in the refrigerator temperature is higher when compared to the $\mathrm{pH}$ of samples stored at room temperature.[7]

Before storage, the addition of different hydrocolloids on the sports energy gel shows the $\mathrm{pH}$ values varying and significantly different $(\mathrm{P}=0.0001)$. It attributes to the presence of a dose of the same hydrocolloid addition to each type to show significant $\mathrm{pH}$ differences even though the dose add in small quantities $(0.1 \% \mathrm{w} / \mathrm{v})$. It is supported by research that has conducted in the year 2012, which shows the results that the addition of xanthan gum and carrageenan with different addition doses is incapable of giving effect to the $\mathrm{pH}$ value and chemical composition of yogurt samples.[8] Similar with the result of the study on aloeveralemon functional drink that showed a significant decrease during storage periods.[9] This study's results differed from the research done on yogurt samples added by several different stabilizer types, where the research results showed a $\mathrm{pH}$ value that did not differ significantly.[10] The decrease in $\mathrm{pH}$ value during storage is associated with a microbiological activity that mainly occurs in samples stored at room temperature. During the storage period in room temperature will increase the rate of breakdown of carbohydrates by microorganisms that will ultimately increase the total levels of acid in the product and decrease the $\mathrm{pH}$ value.[11]

Total Soluble Solid (TSS). Measurement of TSS of sports energy gel during the 7-day storage period results in a sharp decrease on the $1^{\text {st }}$ day in the sample of the added xanthan gum, both stored in room temperature and the refrigerator temperature. Sports energy gel added pectin and CMC showed a decrease in total soluble solid but not as sharp as the sport of energy gel added xanthan gum. Sports energy gel both are stored at room temperature and in the refrigerator temperature $\left(\mathrm{H}_{1} \mathrm{~T}_{1} ; \mathrm{H}_{1} \mathrm{~T}_{2} ; \mathrm{H}_{2} \mathrm{~T}_{1} ; \mathrm{H}_{2} \mathrm{~T}_{2} ; \mathrm{H}_{3} \mathrm{~T}_{1}\right.$; and $\left.\mathrm{H}_{3} \mathrm{~T}_{2}\right)$ shows a consistent decrease in total soluble solids until the $7^{\text {th }}$ day of observation. (Fig. 1c \& 1d)

The results of the different tests using the independent t-test showed no significant differences in TSS between the sports energy gel stored at room or refrigerator temperature $(\mathrm{p}=$ 0.583). However, different test results for each day of observation indicate that there is a significant difference in TSS between sport energy gels stored at room and refrigerator temperature on the $3^{\text {rd }}$ day of observation, indicated by $p$-value $<0.05$ ( $p=0.026 ; 0.024$; $0.0001 ; 0.0001$; and 0.0001 ). The TSS of sports energy gel stored at room and the refrigerator temperature on the $1^{\text {st }}$ and second-day observations showed no significant difference $(\mathrm{p}=$ 0.473 and 0.231) (Table 2). 
ANOVA analysis mentioned that the addition of different types of hydrocolloids to the sports energy gel formulations could show significantly different changes in TSS throughout storage in both room and refrigerator temperature $(\mathrm{p}=0.0001)$. The DMRT test results showed that any sports energy gel that added different hydrocolloid types stored at room temperature had significantly different total soluble solids. It indicates the difference in the letter notation (Fig. 1c \& 2d).

Table 3. Observation of organoleptic characteristics of Sport Energy Gel during storage.

\begin{tabular}{|c|c|c|c|c|c|}
\hline \multirow{2}{*}{ Day } & \multirow{2}{*}{ Treatment } & \multicolumn{4}{|c|}{ Characteristics } \\
\hline & & Color & Odor & Thickness & Physical Appearance \\
\hline \multirow[t]{3}{*}{0} & $\mathrm{H}_{1} \mathrm{~T}_{1}$ & Light purple + & Cucumber +++ & +++ & Normal \\
\hline & $\mathrm{H}_{2} \mathrm{~T}_{1}$ & Light purple ++ & Cucumber +++ & + & Normal \\
\hline & $\mathrm{H}_{3} \mathrm{~T}_{1}$ & Light purple + & Cucumber +++ & ++ & Normal \\
\hline \multirow[t]{6}{*}{3} & $\mathrm{H}_{1} \mathrm{~T}_{1}$ & Purple $+;$ cloudy ++ & Cucumber + ; sour ++ & ++++ & Froth +++ ; fattened + \\
\hline & $\mathrm{H}_{2} \mathrm{~T}_{1}$ & Purple $+;$ cloudy + & Cucumber + ; sour ++ & +++ & Froth ++ ; fattened + \\
\hline & $\mathrm{H}_{3} \mathrm{~T}_{1}$ & Purple $+;$ cloudy + & Cucumber + ; sour ++ & ++ & Froth + \\
\hline & $\mathrm{H}_{1} \mathrm{~T}_{2}$ & Light purple ++ & Cucumber ++ & ++ & Normal \\
\hline & $\mathrm{H}_{2} \mathrm{~T}_{2}$ & Light purple ++ & Cucumber ++ & + & Normal \\
\hline & $\mathrm{H}_{3} \mathrm{~T}_{2}$ & Light purple + & Cucumber ++ & + & Normal \\
\hline \multirow[t]{6}{*}{5} & $\mathrm{H}_{1} \mathrm{~T}_{1}$ & Purple + ; cloudy +++ & Sour +++ & ++++ & Froth ++++ ; fattened ++ ; smoky \\
\hline & $\mathrm{H}_{2} \mathrm{~T}_{1}$ & Purple + ; cloudy ++ & Sour +++ & +++ & Froth $++;$ fattened ++ \\
\hline & $\mathrm{H}_{3} \mathrm{~T}_{1}$ & Purple + ; cloudy ++ & Sour +++ & ++ & Froth ++ \\
\hline & $\mathrm{H}_{1} \mathrm{~T}_{2}$ & Light purple ++ & Cucumber + ; Light sour + & ++ & Sedikit fattened \\
\hline & $\mathrm{H}_{2} \mathrm{~T}_{2}$ & Light purple ++ & Cucumber + ; Light sour + & + & Sedikit fattened \\
\hline & $\mathrm{H}_{3} \mathrm{~T}_{2}$ & Light purple + & Cucumber + ; Light sour + & + & Sedikit fattened \\
\hline \multirow[t]{6}{*}{7} & $\mathrm{H}_{1} \mathrm{~T}_{1}$ & Purple ++ ; cloudy +++ & Sour +++++ & ++++ & Froth ++++; fattened ++ ; smoky \\
\hline & $\mathrm{H}_{2} \mathrm{~T}_{1}$ & Purple $++;$ cloudy ++ & Sour +++++ & +++ & Froth +++ ; fattened ++ \\
\hline & $\mathrm{H}_{3} \mathrm{~T}_{1}$ & Purple $++;$ cloudy ++ & Sour +++++ & ++ & Froth +++ ; fattened + \\
\hline & $\mathrm{H}_{1} \mathrm{~T}_{2}$ & Light purple ++ & $\begin{array}{c}\text { Cucumber }+; \text { Light sour } \\
++\end{array}$ & ++ & Sedikit fattened \\
\hline & $\mathrm{H}_{2} \mathrm{~T}_{2}$ & Light purple ++ & $\begin{array}{c}\text { Cucumber }+; \text { Light sour } \\
++\end{array}$ & + & Sedikit fattened \\
\hline & $\mathrm{H}_{3} \mathrm{~T}_{2}$ & Light purple + & $\begin{array}{c}\text { Cucumber }+ \text {; Light sour } \\
++\end{array}$ & + & Sedikit fattened \\
\hline
\end{tabular}

The results of this study were in line with the research conducted in 2015 on the tomato drink-carrot juice blend, which stated that there was no significant total soluble solid difference between the samples stored at room and the refrigerator temperature.[7] Another study on Aloe vera drinks stored for 60 days showed that a significant decrease in TSS value occurred in all treatments during storage.[12] Total soluble Solid (TSS) is the overall amount of solids dissolved in a solution, such as some types of sugar (sucrose, fructose, and glucose) or other solids such as pectin and certain minerals.[13] In a beverage product that adds with hydrocolloid, the total soluble solid will increase, and its value will differ for each hydrocolloid type. The hydrocolloid structure containing a linear and water-soluble polysaccharides will hydrolyze due to the processing process, which can ultimately improve the simple sugar that appears to increase the TSS value.[14] 


\subsection{Sensory analysis of sport energy gel}

Organoleptic Changes during Storage. Observations of the organoleptic characteristics of the sports energy gel are conducted on 4 points of time $\left(3^{\text {rd }}, 5^{\text {th }}\right.$, and $7^{\text {th }}$ days $)$ during the seven day-period storage for each temperature treatment group (Table 3).

The observed characteristics of organoleptic changes include color, aroma, viscosity, and physical appearance of sports energy gel. In general, organoleptic characteristics of the sports energy gel store at the refrigerator temperature and the room temperature decreased during the storage period. The characteristics of organoleptic sports energy gel stored at room temperature more rapidly decrease when compared with the sports energy gel stored at the refrigerator temperature. The characteristics of sport energy gels stored in refrigerators tend to be more stable and decrease slower during storage periods. During storage, the color of the sports energy gel stored at room temperature changes to be darker than those stored at the refrigerator temperature. The cucumber aroma that is a smell to the sports energy gel stored at the refrigerator temperature can last longer than stored at room temperature. The pungent acid aroma is accompanied by froth and smoky when the lid of the bottle opens, which shows in the sample of sports energy gel stored at room temperature.

The result of the sensory evaluation characteristic done in cloudy ready-to-drink Mulberry product showed that the physical appearance, color, flavor, texture, and the acceptability of the product did not differ significantly in a sample that adds xanthan gum and CMC. The research mentions that the type of hydrocolloids used does not affect the sensory parameters of the product. Although there are significant odor differences between the products that add xanthan gum or CMC.[15]

Homogeneity of Sport Energy Gel. Observation of the energy gel sports homogeneities is also performed on 4 points of time $\left(3^{\text {rd }}, 5^{\text {th }}\right.$, and $7^{\text {th }}$ day) during the seven day-period storage for each temperature treatment group. A gel product is said to be homogeneous when there is no coarse grain or split blob.[6]

Based on observations, the results show that the homogeneity of the sports energy gel stored at room temperature or room temperature decreased during the storage period. The sports energy gel that stores at room temperature indicates the agglomeration of Chia seeds on the surface on day- 3 of storage and increases until $7^{\text {th }}$-day storage. The sports energy gel that stores at the refrigerator temperature also begins to show a reduction in Chia seed's homogeneity in the base of the bottle on day- 3 of storage and consistent until the $7^{\text {th }}$ day of storage. There was no stability in the gel homogenized; the sports energy gel product in this study associated with the low number of hydrocolloids added in the product so that the product's homogeneity decreased faster during the duration of storage. Unlike the results of this study, the research on the Chinese scalloped extract gel shows more stable homogeneity of the gel during the storage period.[16] The limitation of this study is there is no physicochemical and sensory as the gold standard to assess the suitability of the sport energy gel characteristics prooduced. 


\section{Conclusion}

The energy gel sports storage added by a variety of hydrocolloids for seven-days with different storage temperatures may result in significant physical and sensory characteristics. Seven days of storage at room and the refrigerator temperature can significantly lower the $\mathrm{pH}$ value and total soluble solid. Sensory characteristics in the form of color, aroma, viscosity, natural tone and homogeneity of sports energy gel stored at room and the refrigerator temperature show a noticeable decline. The sports energy gel that stores at the refrigerator temperature also decreases sensory quality and hmogeneity but appears slower. Researchers suggest that there is need a further research to study appropriate processing methods to enhance better the physicochemical and sensory characteristics and the longer shelf life of the energy gel. Besides, researchers also suggested that there is a need to test advanced sports energy gel products in vivo and examine their impact on living beings.

\section{References}

[1] Julio C, Andr C, Sof C, Ripoll S. Development of mango (Mangifera indica L.) energy drinks. RevFacNacAgron. 2017;70(1):8115-21.

[2] Rachna M, Faridabad S, Rachna M, Faridabad S. Product development, nutrient and sensory analysis of sports drink based on chia seeds (Salvia hispanica L.). Int J Physiol Nutr Phys Educ. 2019;4(2):187-90.

[3] Manarisip T, Yamlean PVY, Lolo WA. Formulasi dan Uji Efektivitas Antibakteri Sediaan Gel Ekstrak Etanol Daun Kersen (Muntingia calabura L.) SEBAGAI. Pharmacon. 2019;8(3):165-75.

[4] Ihsan, Farihul \& Wahyudi A. Teknik Analisis Kadar Sukrosa pada Buah Pepaya. Bul Tek Pertan. 2010;15(1):10-2.

[5] Daswi DR, Stevani H, Santi E, Farmasi J, Kemenkes P. Uji Stabilitas Mutu Fisik Sediaan Masker Gel Wajah dari Ekstrak Daun Belimbing Wuluh (Averrhoe blimbi, L) dengan Variasi Konsentrasi Carbopol. Media Farm. 2018;XIV(1):85-92.

[6] Kumesan YAN, Yamlean PVY, Supriati HS, Studi P, Unsrat F. Formulasi dan Uji Aktivitas Gel Antijerawat Ekstrak Umbi Bakung (Crinum asiaticum L .) Terhadap Bakteri Staphylococcus Aureus Secara In Vitro. Pharmacon. 2013;2(02):18-27.

[7] Nwaokoro OG, Akanbi CT. Effect of the Addition of Hydrocolloids to Tomato-Carrot Juice Blend. J Nutr Heal Food Sci. 2015;3(1):1-10.

[8] N Hematyar, AM Samarin HP and AE. Effect of Gums on Yogurt Characteristics. World Appl Sci J. 2019;20(5):661-5.

[9] Kausar H, Parveen S, Saeed S, Ishfaq B, Ali MA. Development and Standardization of Ready to Serve Aloevera- Lemon Functional Drink. 2016;10(4):47-52.

[10] Sobhay ATH, Awad RA, Hassan ZMR E-BO. Properties of Drinking Yoghurt using Different Types of Stabilizers. Arab Univ J Agric Sci. 2019;27(1):431-40.

[11] Ashaye, OA, Taiwo OO AG. Effect of local preservative (Aframomum danielli) on the chemical and sensory properties of stored warakanshi. African J Agric Res. 2006;1(1):010-6.

[12] Masood MA, Shah F, Bashir S, Jamil R. Effect of storage on the physiochemical and antioxidant properties of Aloe vera drink. Int J Food Sci Nutr. 2019;4(4):201-5.

[13] LS Magwazaa \& UL Opara. Analytical methods for determination of sugars and sweetness of horticultural products - A review. Sci Hortic (Amsterdam) [Internet]. 2015;184:179-92. Available from: http://dx.doi.org/10.1016/j.scienta.2015.01.001

[14] N H R Parnanto, B Yudhistira SRP and AP. The effect of CMC and arabic gum stabilizer combination on the characteristics of soursop velva ( Annona muricata L .) The effect of CMC and ara- 
bic gum stabilizer combination on the characteristics of soursop velva (Annona muricata L.). In: IOP Conference Series: Earth and Environmental Science 142. 2018. p. 1-6.

[15] Suthida A, Sirikhwan T. Effects of types and amounts of stabilizers on physical and sensory characteristics of cloudy ready-to-drink mulberry fruit juice. Food Sci Nutr. 2015;3(3):213-20.

[16] NA Sayuti. Artikel Riset Formulasi dan Uji Stabilitas Fisik Sediaan Gel Ekstrak Daun Ketepeng Cina (Cassia alata L.). J Kefarmasian Indones. 2015;5(2):74-82. 